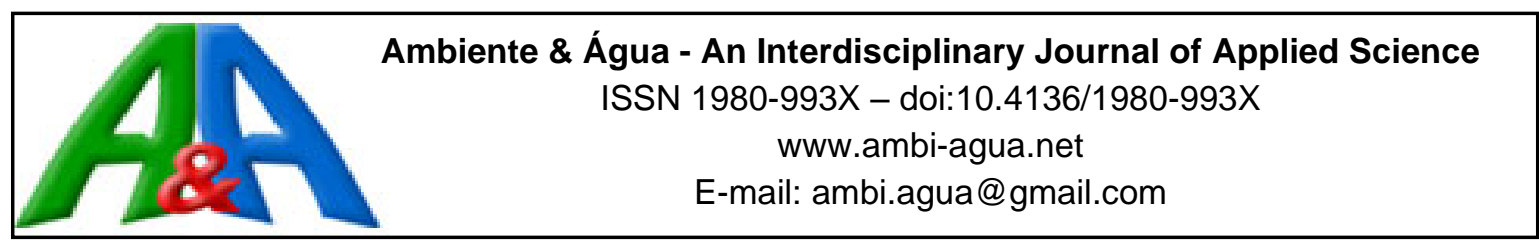

\title{
DOF/DAF comparison for the treatment of milk industry wastewater
}

\author{
ARTICLES doi:10.4136/ambi-agua.2553
}

Received: 30 Mar. 2020; Accepted: 07 Jul. 2020

\section{Magno dos Santos Pereira ${ }^{(D}$; Alisson Carraro Borges* ${ }^{*}$; Gustavo Lopes Muniz ${ }^{\circledR}$; Fernanda Fernandes Heleno $D^{D}$, Lêda Rita D'Antonino Faroni $i$}

\author{
Departamento de Engenharia Agrícola. Universidade Federal de Viçosa (UFV), Avenida PH Rolfs, s/n, \\ CEP: 36570-900, Viçosa, MG, Brazil. E-mail: magno.pereira@ufv.br, gustavolopesmuniz@yahoo.com.br, \\ fernanda.heleno@ufv.br, lfaroni@ufv.br \\ *Corresponding author. E-mail: borges@ufv.br
}

\begin{abstract}
The objective of this study was to evaluate the efficiency of dissolved ozone flotation (DOF) in comparison to dissolved air flotation (DAF) for treatment of milk industry wastewater (MW). In the first phase of the experiment, a synthetic milk wastewater (SMW) was used to evaluate DOF and DAF, with and without addition of hydrogen peroxide, at $\mathrm{pH} 4.0$ and $\mathrm{pH}$ 11.4. In the DOF tests, the concentration of ozone was equal to $19( \pm 0.5) \mathrm{mg} \mathrm{L}^{-1}$ and in the tests with addition of hydrogen peroxide, the $\mathrm{H}_{2} \mathrm{O}_{2} / \mathrm{O}_{3}$ ratios tested were $0.5,1.0$ and 1.5. In the second phase, tests were performed using three MW from three different industries to validate the results obtained and to determine the DOF system's ability to treat this type of effluent. The parameters tested during validation were turbidity, total suspended solids, oils and greases $(\mathrm{O} \& \mathrm{G})$, chemical oxygen demand (COD), biochemical oxygen demand (BOD), total nitrogen (TN) and total phosphorus (TP). It was observed that the efficiency of the treatments was better at $\mathrm{pH}$ 4.0. The results showed a reduction of the efficiency with the use of DOF. The addition of $\mathrm{H}_{2} \mathrm{O}_{2}$ in DAF and DOF also resulted in reduced system efficiency. The results obtained with SMW only approximated those obtained with the MW from one of the industries that contained the largest traces of milk and cheese.
\end{abstract}

Keywords: advanced oxidation process, dairy wastewater, dissolved ozone flotation.

\section{Comparação entre FAD e FAOD para o tratamento da água residuária de laticínios}

\section{RESUMO}

O objetivo deste estudo foi avaliar a eficiência da flotação por ar e ozônio dissolvido (FAOD) em comparação à flotação por ar dissolvido (FAD) no tratamento da água residuária de laticínios (ARL). Na primeira fase do experimento foi utilizada água residuária de laticínios sintética (ARLS) para avaliar a FAD e a FAOD, com e sem a adição de peróxido de hidrogênio em dois valores de $\mathrm{pH}, 4,0$ e 11,4. Nos testes de FAOD, a concentração de ozônio utilizada no ar foi igual a $19( \pm 0,5) \mathrm{mg} \mathrm{L}^{-1}$ e nos testes com adição de peróxido de hidrogênio, as relações $\mathrm{H}_{2} \mathrm{O}_{2} / \mathrm{O}_{3}$ testadas foram de $0,5,1,0$ e 1,5 . Na segunda parte do experimento, foram realizados testes com três ARL de três diferentes laticínios para validar os resultados obtidos e determinar a capacidade do sistema FAOD para tratar esse tipo de efluente. Os parâmetros testados durante a validação foram: turbidez, sólidos totais suspensos, óleos e graxas (O\&G), demanda química 
de oxigênio (DQO), demanda bioquímica de oxigênio (DBO), nitrogênio total $\left(\mathrm{N}_{\mathrm{T}}\right)$ e fósforo total $\left(\mathrm{P}_{\mathrm{T}}\right)$. Ao final do experimento, observou-se que a eficiência dos tratamentos foi melhor em pH 4. Os resultados mostraram uma redução da eficiência com o uso da FAOD. A adição de $\mathrm{H}_{2} \mathrm{O}_{2}$ na FAD e FAOD também resultou em menor eficiência nos dois sistemas. Os resultados obtidos com ARLS aproximaram-se apenas dos obtidos com o ARL de uma das indústrias que continham os maiores traços de leite e queijo.

Palavras-chave: efluentes de laticínios, flotação por ozônio dissolvido, processos oxidativos avançados.

\section{INTRODUCTION}

The traditional biological treatment systems present unsatisfactory results when applied to the degradation of effluents that have a high amount of bio refractory compounds (such as effluents from agri-food industries) and the development of chemical oxidation strategies becomes necessary (Martins and Quinta-Ferreira, 2014).

Ozone is a powerful oxidizing compound $\left(\mathrm{E}^{\mathrm{o}}=2.07 \mathrm{~V}\right)$ capable of reacting with various chemical species under normal conditions of pressure and temperature.

In simple ozonation (without catalyst), ozone has a double action on the pollutants according to the $\mathrm{pH}$ of the medium. At low $\mathrm{pH}$ values $(\mathrm{pH} \leq 4)$, ozone reacts directly and selectively with compounds that have sites of high electron density such as chromophoric groups and with unsaturated bonds. For alkaline conditions $(\mathrm{pH}>10)$, hydroxide ions promote the molecular decomposition of ozone into hydroxyl radicals capable of decomposing a broader range of organic pollutants (free radical pathways). For $\mathrm{pH}$ around 7, both reaction pathways are present. Thus, there were different ways in which ozone can react with polluting organic compounds. The decomposition of ozone in water can also be caused by UV radiation and hydrogen peroxide (Mahmoud and Freire, 2007; Martins and Quinta-Ferreira, 2014; Shokri, 2015; Shokri et al., 2015).

The homogeneous combination between ozone $\left(\mathrm{O}_{3}\right)$ and hydrogen peroxide $\left(\mathrm{H}_{2} \mathrm{O}_{2}\right)$ is considered a promising alternative in the removal of organic compounds from effluents. The conjugated base of hydrogen peroxide, in low concentrations, can initiate the decomposition of ozone much more rapidly, generating $\mathrm{OH}^{\bullet}$, than the hydroxide ion $\left(\mathrm{OH}^{-}\right)(\mathrm{Catalkaya}$ and Kargi, 2007). The generation of hydroxyl radicals through the combination of ozone and hydrogen peroxide is based on Equation 1 (Jaafarzadeh et al., 2017; Ahmadi and Ghanbari, 2018).

$$
2 \mathrm{O}_{3}+2 \mathrm{HO}_{2}^{-}+\mathrm{H}_{2} \mathrm{O} \rightarrow 2 \mathrm{HO}^{\bullet}+3 \mathrm{O}_{2}+\mathrm{OH}^{-}+\mathrm{HO}_{2}^{-\bullet}
$$

Dissolved ozone flotation (DOF) is an innovative water treatment process that combines the benefits of ozonation and flotation. Consequently, coagulation, separation, discoloration, odor removal and disinfection can occur simultaneously in DOF systems (Jin et al., 2015). Other benefits are: reduction in coagulant/flocculant dosage; removal of pathogens; increased biodegradability of effluents; removal of micro pollutants and reduction of the amount of biological sludge generated (Wilinski and Naumczyk, 2012).

In the past, ozone research used conventional flotation (thick bubbles), not micro or nano flotation, thus omitting the essential factor in the process. The main parameter that may limit the kinetics of the process is the mass transfer of the ozone to the liquid (Wilinski and Naumczyk, 2012).

The efficiency of the process depends on the total area of ozone bubbles in solution, because a larger area (amount of bubbles generated) increases the mass transfer of ozone and the oxidation rate of organic compounds. In conclusion, the problem of mass transfer of the ozone to the liquid medium can be solved using appropriate air dispersion technologies (micro- 
and nano-bubble generating systems) (Wilinski and Naumczyk, 2012).

Lee et al. (2008) compared the efficiencies of the dissolved ozone flotation system, and associated costs, with other technologies such as conventional ozonation, membrane filtration, electro flocculation ozonation, electrodialysis, and sand filtration followed by chlorination. According to the authors, DOF technology is highly effective and economically feasible for the treatment of effluents these days.

Due to these facts, DOF has become increasingly popular in effluent treatment. Compared to the conventional treatment process, which consists of coagulation, sedimentation and filtration, the DOF process is superior in removal of color, odor and organic matter from effluents. In addition, the hydraulic retention time (HRT) of the DOF process is three times lower than the conventional tertiary wastewater treatment process, which results in much smaller space requirements (Jin et al., 2015).

The objective of this experiment was to evaluate flotation by dissolved ozone, with and without the addition of hydrogen peroxide, compared to dissolved air flotation for the treatment of milk wastewater.

\section{MATERIALS AND METHODS}

\subsection{Samples, reagents and solutions used}

In the experiment, a synthetic milk wastewater (SMW) was used, as suggested by Silva et al. (2013). According to the authors, this formulation satisfactorily characterizes a synthetic effluent that does not contain whey derived from the manufacture of cheese. The average composition of the synthetic milk effluent used in the experiment was: $\mathrm{pH}$ equal to $7.6 ; 3065.0$ $\mathrm{mg} \mathrm{L}^{-1}$ of COD; 625.0 NTU of turbidity; $186.0 \mathrm{mg} \mathrm{L}^{-1}$ of O\&G; $3974.0 \mathrm{mg} \mathrm{L}^{-1}$ of total solids (TS); $282.0 \mathrm{mg} \mathrm{L}^{-1}$ of total suspended solids (TSS) and $1367.0 \mathrm{mg} \mathrm{L}^{-1}$ of alkalinity as $\mathrm{CaCO}_{3}$.

The agro-industrial effluent samples were collected from three milk industries in the region of Viçosa-MG. The samples, either synthetic or from the industries, were used on the same day of the tests or on the day immediately after collection, being in this case conserved at $5^{\circ} \mathrm{C}$.

The hydrogen peroxide solutions were prepared using a $30 \% \mathrm{w} / \mathrm{w} \mathrm{H}_{2} \mathrm{O}_{2}$ solution, $\left[\mathrm{H}_{2} \mathrm{O}_{2}\right]$ $=9.0 \mathrm{~mol} \mathrm{~L}^{-1}$ and density of $1.1 \mathrm{~g} \mathrm{~mL}^{-1}$. The coagulant used was ferrous sulfate heptahydrate $\left(\mathrm{FeSO}_{4} .7 \mathrm{H}_{2} \mathrm{O}\right)$. The $\mathrm{pH}$ was adjusted using 1:1 v/v solutions of sodium hydroxide $(\mathrm{NaOH})$ or hydrochloric acid $(\mathrm{HCl})$.

\subsection{Obtaining and measuring of ozone gas in air and water}

Ozone gas was obtained from an ozone generator developed by the company Ozone \& Life (São José dos Campos, SP), being used in the oxygen process (90-95\% purity) after drying and concentration of atmospheric air in the equipment.

The concentration of ozone in the air stream at a flow rate of $5 \mathrm{~L} \mathrm{~min}^{-1}$ was determined immediately before of the saturation chamber by the iodometric method (APHA et al., 2012), having a value equal to $19( \pm 0.5) \mathrm{mg} \mathrm{L}^{-1}$, which was used throughout the experiment.

The ozone dissolved in water, measured in distilled water after the release of the supersaturated water with the ozone at atmospheric pressure, was determined by the DDPD method using a Vacu-vials kit from CheMetrics, having a value equal to $5.3( \pm 0.3) \mathrm{mg} \mathrm{L}^{-1}$.

\subsection{Experimental planning}

The experiment consisted of the evaluation of the dissolved ozone flotation system (DOF), with and without the addition of hydrogen peroxide $\left(\mathrm{H}_{2} \mathrm{O}_{2}\right)$, compared to the traditional dissolved air flotation system (DAF). The tests were carried out in acidic $(\mathrm{pH}=4)$ and basic $(\mathrm{pH}=11.4)$ medium for the evaluation of the different effects of ozone on the treatment efficiency at each $\mathrm{pH}$ range of the solution.

In the tests with peroxide addition, the $\mathrm{H}_{2} \mathrm{O}_{2} / \mathrm{O}_{3}$ ratios of $0.5,1.0$ and 1.5 , calculated on the 
basis of the mass of ozone released into the flotation column, were tested according to Equation 2 adapted from Edzwald and Haarhoff (2011). Hydrogen peroxide was added and mixed to the samples in the flotation column immediately prior to flotation tests (with and without ozone).

$$
M_{o Z}=44.6 \times 10^{-3} x\left(\frac{273.15}{273.15+T}\right) \times\left(\frac{P_{a b s}}{101.3}\right) \times\left(\frac{M}{H e} \times f_{x}\right) \times \frac{R R}{100} \times V_{M W}
$$

Where: $\mathrm{M}_{\mathrm{oz}}$ - mass of ozone liberated in the flotation column (mg); $\mathrm{T}$ - solution temperature, equal to $20^{\circ} \mathrm{C} ; \mathrm{P}_{\mathrm{abs}}$ - absolute pressure within the saturation chamber, equal to $919.2 \mathrm{kPa} ; \mathrm{M}$ - ozone molar mass, equal to $48000 \mathrm{mg} \mathrm{mol}^{-1}$; He - Henry's constant for ozone, equal to $3.408 ; \mathrm{f}_{\mathrm{x}}-$ molar fraction of the ozone in the gas stream, equal to $9.56 \times 10^{-3}$; RR recirculation rate, equal to $20 \%$; $\mathrm{V}_{\mathrm{MW}}$ - milk wastewater sample volume, equal to $2 \mathrm{~L}$.

The steps of the first part of the experiment are summarized in Table 1; in all of them, three replicates of each treatment were made. For the determination of the best treatment and evaluation of the efficiency of the system in each treatment, analyses of turbidity, COD, total organic carbon (TOC) and color were made.

Table 1. Stages of the experiment for the evaluation of dissolved ozone flotation, with and without addition of hydrogen peroxide, using the synthetic milk wastewater.

\begin{tabular}{cc}
\hline Stages of the experiment & Description \\
\hline 1 & Dissolved air flotation tests \\
2 & Dissolved ozone flotation tests \\
3 & Dissolved air flotation tests with addition of $\mathrm{H}_{2} \mathrm{O}_{2}$ \\
4 & Dissolved ozone flotation tests with addition of $\mathrm{H}_{2} \mathrm{O}_{2}$ \\
\hline
\end{tabular}

After the determination of the best treatment, whether at $\mathrm{pH} 4$ or 11.4 and with or without $\mathrm{H}_{2} \mathrm{O}_{2}$ addition, tests of DAF and DOF were performed using the three milk effluents cited for validation of the best treatment. For the validation, the parameters of turbidity, chemical oxygen demand (COD), biochemical oxygen demand (BOD), oils and greases (O\&G), total suspended solids (TSS), total nitrogen (NT) and total phosphorus (PT) were analyzed, according to APHA et al. (2012).

The color analysis was done using a Konica Minolta colorimeter, Model Chroma Meters CR-400, as presented in Equation 3 (MacDougall, 2002).

$$
\text { Delta color }=\sqrt{\left(L-L_{0}\right)^{2}+\left(a-a_{0}\right)^{2}+\left(b-b_{0}\right)^{2}}
$$

Where: Delta color - color variation of the treated sample; L - luminosity of the treated sample; $\mathrm{L}_{0}$ - luminosity of distilled water; a - red/green coordinate (+a indicates red and -a indicates green) of the treated sample; a - red/green coordinate ( $+\mathrm{a}$ indicates red and -a indicates green) of the distilled water; $b-$ yellow/blue coordinate $(+b$ indicates yellow and $-b$ indicates blue) of the treated sample; $b_{0}-$ yellow/blue coordinate $(+b$ indicates yellow and $-b$ indicates blue) of the distilled water.

The values obtained for the parameters (turbidity, delta color, COD, BOD, O\&G, TSS, TN and TP) after analysis were corrected using Equation 4 due to the dilution effect caused by the water injection of the saturation chamber in the flotation column.

$$
P_{\text {cor }}=P_{\text {mes }} x\left(\frac{100+R R}{100}\right)
$$


Where: $\mathrm{P}_{\text {cor }}$ - corrected parameter value; $\mathrm{P}_{\text {mes }}$ - value of the measured parameter; $\mathrm{RR}$ recirculation ratio, equal to $20 \%$.

For the statistical analysis of the results, the Tukey test was used to compare means at a significance level of $5 \%$.

\subsection{Used system and operating conditions}

A batch dissolved ozone flotation system composed of an air compressor, a pressure regulating valve, a saturation chamber for the dissolution of the gas mixture and a flotation column was used in the experiment (Figure 1).

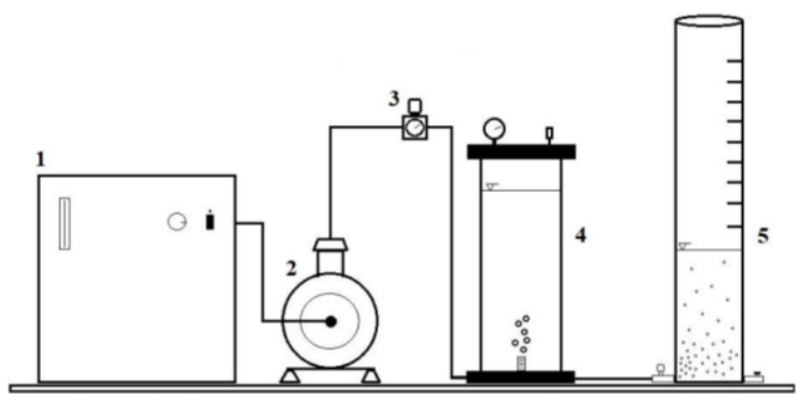

Figure 1. System used in the experiment. 1 - ozone generator; 2 - compressor; 3 - pressure regulator; 4 - saturation chamber; 5 - flotation column.

The operating conditions of the flotation system were: saturation pressure of 10 bar; recirculation ratio of $20 \%$; flotation speed of $10 \mathrm{~cm} \mathrm{~min}^{-1}$; speed gradient for coagulation of $220.0 \mathrm{G}$; speed gradient for flocculation of $80 \mathrm{G}$; flocculation time equal to 5 min and $\mathrm{FeSO}_{4}$ dose equal to $250,0 \mathrm{mg} \mathrm{\textrm {L } ^ { - 1 }}$. The parameters were adopted according to Edzwald's recommendation (Edzwald, 2010) and based on preliminary tests.

The flotation was done using the same procedure in all the tests. The air and ozone mixture were injected by the lower inlet and dissolved in potable water until the pressure of 10 bar was attained in the saturation chamber. After reaching the pressure inside the saturation chamber, the gas injection was maintained for $2 \mathrm{~min}$ for the saturation of the water. In sequence, the valve of the pipeline connecting the saturation chamber to the flotation column was opened by injecting the supersaturated water with air and ozone into the flotation column.

To maintain the pressure established in the saturation chamber, during the opening of the valve, air was injected through the upper opening of the saturation chamber to compensate for the pressure drop caused by the water exhaust of the chamber. By the process, a maximum pressure drop of 1 bar was obtained during the entire process of water release in the flotation column.

The inlet air flow into the system was adjusted to $5 \mathrm{~L} \mathrm{~min}^{-1}$ and the flotation velocity in the flotation column was set to $10.0 \pm 1 \mathrm{~cm} \mathrm{~min}^{-1}$ using needle valves in both cases.

After injection of the volume of water corresponding to the pre-established recirculation ratio, the chamber water outlet valve was closed, with the water and gas injection being withdrawn into the flotation column. After $5 \mathrm{~min}$ of flotation start, the valve was closed, and $500 \mathrm{~mL}$ of the clarified samples were collected in each trial from the bottom of the flotation column.

\section{RESULTS AND DISCUSSION}

Table 2 shows the results of the comparative tests between DAF and DOF in acidic and basic medium, respectively, using synthetic milk wastewater (SMW). 
Table 2. Results of trials in acid and basic medium.

\begin{tabular}{clcccccccc}
\hline \multirow{2}{*}{$\mathrm{pH}$} & Parameters & \multicolumn{9}{c}{ DAF } & \multicolumn{3}{c}{ DOF } \\
\cline { 3 - 9 } & & Mean & SD & CV & Efficiency & Mean & SD & CV & Efficiency \\
\hline \multirow{4}{*}{4} & Turbidity & 96.7 & 2.7 & 2.8 & $84.5(\mathrm{a})$ & 141.6 & 3.2 & 2.2 & $77.3(\mathrm{~b})$ \\
& Delta color & 2.4 & 0.04 & 1.7 & $83.1(\mathrm{a})$ & 2.9 & 0.2 & 6.0 & $79.8(\mathrm{~b})$ \\
& COD & 385.5 & 25.6 & 6.6 & $87.5(\mathrm{a})$ & 246.4 & 5.7 & 2.3 & $92.0(\mathrm{~b})$ \\
& TOC & 641.1 & 7.2 & 1.1 & $53.8(\mathrm{a})$ & 650.0 & 5.9 & 0.9 & $53.2(\mathrm{a})$ \\
\hline \multirow{3}{*}{11.4} & Turbidity & 1192.0 & 22.8 & 1.9 & $-90.7(\mathrm{a})$ & 1361.6 & 12.1 & 0.9 & $-119.6(\mathrm{~b})$ \\
& Delta color & 18.2 & 0.3 & 1.6 & $-27.9(\mathrm{a})$ & 18.8 & 0.3 & 1.6 & $-32.1(\mathrm{a})$ \\
& COD & 2571.0 & 23.8 & 0.9 & $17.9(\mathrm{a})$ & 2632.0 & 22.9 & 0.9 & $15.9(\mathrm{a})$ \\
& TOC & 940.1 & 87.9 & 9.4 & $29.4(\mathrm{a})$ & 908.2 & 61.4 & 6.8 & $31.8(\mathrm{a})$ \\
\hline
\end{tabular}

Note: CV - Coefficient of variation (in percentage); SD - Standard deviation (in percentage); Efficiency of removal (in percentage); Turbidity in NTU; Delta color - dimensionless; COD in $\mathrm{mg} \mathrm{L}^{-1}$; $\mathrm{pH}$ dimensionless; TOC in $\mathrm{mg} \mathrm{L}^{-1}$. Values on the same line followed by the same letter do not differ statistically by the Tukey test for a significance level equal to $5 \%$.

It can be observed in Table 2 that for all the tested parameters, the best results were obtained in acidic medium $(\mathrm{pH}=4)$ for DAF and DOF. Evaluating the result of each parameter alone, it is verified that for the acid medium only COD removal was statistically higher in DOF compared to DAF.

The negative results presented in Table 2 for turbidity and color are due to the higher values obtained at the end of the test compared to their initial values in the SMW (Table 1). The measured final turbidity was higher due to addition of the coagulant and the precipitation of flocs in the lower part of the flotation column or their permanence at suspension in the liquid after the flotation not being removed in the process.

There is also a tendency for ferrous sulphate to precipitate due to the formation of an iron hydroxide $\left(\mathrm{FeOH}_{2}\right.$ or $\left.\mathrm{FeOH}_{3}\right)$ gel at $\mathrm{pH}$ above 9, which leads to the formation of large and heavy flocs by the swapping effect at coagulation, which are hardly removed by DAF (Arslan, 2001).

Solid ferrous sulfate in the FeSO4.7H2O form has a light green color and may take on a yellowish, brownish, reddish brown or green color depending on the $\mathrm{pH}$ of the medium. Its reaction with $\mathrm{NaOH}$ produces $\mathrm{Fe}(\mathrm{OH})_{2}$ that has green coloration and takes darker shades with increasing $\mathrm{pH}$.

The treatment efficiency was mainly due to flotation, since ozone had a small or negative effect in the removal of most of the analyzed parameters as can be observed in Table 2 . The best results in acidic medium are due to the natural coagulation of casein at $\mathrm{pH}$ close to 4.6 (Prazeres et al., 2012), which favored the coagulation process and their removal at DAF or DOF trials.

A similar adverse effect of ozone on coagulation and particle removal efficiency was observed by Liu et al. (2006), Ntampou et al. (2006) and Liu et al. (2015).

During a study about the effects of ozone at coagulation, according to Liu et al. (2006) it was not possible to observe any beneficial effect on coagulation with the pre-ozonation of the samples, causing on the contrary deterioration of the coagulation efficiency, with delay in the formation of flocs and reduction in the removal of turbidity, dissolved organic carbon (DOC) and color $\left(\mathrm{UV}_{254}\right)$. According to the authors, after ozonation, there was only a $5 \%$ increase in DOC removal and a higher hydrophilicity was observed, which impaired DOC removal in the coagulation process. They also reported that the dose of ozone and the characteristics of the organic substances are the two main factors that affect the performance of the coagulation.

Ozonation can oxidize organic compounds by reducing their molecular weight and can

Rev. Ambient. Água vol. 15 n. 5, e2553 - Taubaté 2020 
also increase the amount of acidic functional groups, affecting in various ways the interaction between the organic matter and the coagulating agent. It may affect the coagulation of organic matter, mainly by altering the electrostatic interactions between the coagulant and the organic molecules, rather than altering the intrinsic affinity of the compounds by adsorptive sites on the surface of the coagulant. Therefore, the impact of ozonation on coagulation will depend on the characteristics of the treatment system, the particles and the type of coagulant used (Ntampou et al., 2006).

Ozonation may also reduce the concentration of hydrolyzed aluminum species (eg: $\left.\left[\mathrm{Al}(\mathrm{OH})\left(\mathrm{H}_{2} \mathrm{O}\right)_{5}\right]^{2+},\left[\mathrm{Al}(\mathrm{OH})_{2}\left(\mathrm{H}_{2} \mathrm{O}\right)_{4}\right]^{+}, \mathrm{Al}(\mathrm{OH})_{3}\right)$ and iron $\left(\mathrm{eg}: \mathrm{Fe}_{2} \mathrm{O}_{3}, \mathrm{Fe}(\mathrm{OH}) \mathrm{SO}_{4}, \mathrm{Fe}_{2}(\mathrm{SO} 4)_{3}\right.$, $\mathrm{FeOH}_{2}$ ), responsible for particle coagulation (Liu et al., 2015; Richter, 2009).

Another factor that may have contributed to the fact that ozone did not have a positive effect in increasing the treatment efficiency is the high alkalinity of the SMW (1367.0 $\left.\mathrm{mg} \mathrm{L}^{-1}\right)$ caused by the presence of bicarbonates $\left(\mathrm{HCO}_{3}{ }^{-}\right)$or carbonates $\left(\mathrm{CO}_{3}{ }^{2-}\right)$ that can act as sequestrants of the hydroxyl radicals (Beltrán, 2004).

Table 3 presents the results of the comparative tests between DAF and DOF with the addition of hydrogen peroxide, in acidic and basic medium, using the synthetic milk wastewater (SMW).

Table 3. Results of dissolved air flotation and dissolved ozone flotation trials in acid and basic medium with addition of hydrogen peroxide.

\begin{tabular}{|c|c|c|c|c|c|c|}
\hline \multirow{2}{*}{$\mathrm{pH}$} & \multirow{2}{*}{\multicolumn{2}{|c|}{$\mathrm{H}_{2} \mathrm{O}_{2} / \mathrm{O}_{3}$ ratio }} & \multicolumn{4}{|c|}{ Parameters } \\
\hline & & & Turbidity & Delta color & COD & TOC \\
\hline \multirow{12}{*}{4.0} & \multirow{4}{*}{0.5} & Mean & 151.2 & 4.7 & 547.54 & 595.27 \\
\hline & & $\mathrm{SD}$ & 1.2 & 0.23 & 42.3 & 27.65 \\
\hline & & $\mathrm{CV}(\%)$ & 0.79 & 4.97 & 7.73 & 4.64 \\
\hline & & Efficiency (\%) & 75.8 (a) & $66.8(\mathrm{a})$ & 82.0 (a) & 49.3 (a) \\
\hline & \multirow{4}{*}{1.0} & Mean & 285.6 & 6.63 & 676.18 & 602.74 \\
\hline & & SD & 2.4 & 0.52 & 17.85 & 29.38 \\
\hline & & $\mathrm{CV}(\%)$ & 0.84 & 7.81 & 2.64 & 4.87 \\
\hline & & Efficiency (\%) & 54.3 (b) & $53.3(\mathrm{~b})$ & 77.7 (b) & 48.8 (a) \\
\hline & \multirow{4}{*}{1.5} & Mean & 419.2 & 7.17 & 856.27 & 655.85 \\
\hline & & SD & 43.34 & 1.43 & 35.7 & 44.56 \\
\hline & & $\mathrm{CV}(\%)$ & 10.34 & 19.93 & 4.17 & 6.79 \\
\hline & & Efficiency (\%) & $32.9(\mathrm{c})$ & 49.5 (b) & $71.8(\mathrm{c})$ & 45.0 (a) \\
\hline \multirow{12}{*}{11.4} & \multirow{4}{*}{0.5} & Mean & 1101.6 & 18.31 & 2777.3 & 1025.8 \\
\hline & & SD & 4.8 & 0.27 & 81.51 & 74.76 \\
\hline & & $\mathrm{CV}(\%)$ & 0.44 & 1.48 & 2.93 & 7.29 \\
\hline & & Efficiency $(\%)$ & $-76.3(a)$ & $-28.9(a)$ & 8.1 (a) & 19.3 (a) \\
\hline & \multirow{4}{*}{1.0} & Mean & 983.20 & 17.70 & 2688.7 & 1174.9 \\
\hline & & SD & 4.74 & 14.62 & 43.96 & 35.99 \\
\hline & & $\mathrm{CV}(\%)$ & 0.48 & 82.56 & 1.64 & 3.06 \\
\hline & & Efficiency $(\%)$ & $-57.3(b)$ & $-24.7(a)$ & $10.98(a)$ & 7.60 (a) \\
\hline & \multirow{4}{*}{1.5} & Mean & 873.60 & 18.20 & 2205.6 & 1012.4 \\
\hline & & SD & 25.29 & 0.38 & 17.15 & 44.11 \\
\hline & & $\mathrm{CV}(\%)$ & 2.89 & 2.11 & 0.78 & 4.36 \\
\hline & & Efficiency (\%) & $-39.8(\mathrm{c})$ & $-28.2(a)$ & $27.0(\mathrm{~b})$ & 20.4 (a) \\
\hline
\end{tabular}

Note: Turbidity in NTU; Delta color - dimensionless; COD in $\mathrm{mg} \mathrm{L}^{-1} ; \mathrm{pH}$ - dimensionless; TOC in $\mathrm{mg}$ $\mathrm{L}^{-1}$; Values in the same column followed by the same letter do not differ statistically by the Tukey test for a significance level equal to $5 \%$. 
In Table 3, it can be observed that the addition of hydrogen peroxide in the $\mathrm{H}_{2} \mathrm{O}_{2} / \mathrm{O}_{3}$ ratios of $0.5,1$ and 1.5 did not lead to an improvement in the removal efficiency of the parameters evaluated. In the acidic medium there was a reduction in the treatment efficiency as the $\mathrm{H}_{2} \mathrm{O}_{2} / \mathrm{O}_{3}$ ratio increased. In the basic medium there was a small improvement in removal of turbidity and COD with increase of the ratio, but all the parameters had worse results compared to the treatments without addition of hydrogen peroxide (Table 2).

Effect similar to that described for ozone may have occurred with addition of hydrogen peroxide in the sample, resulting in a reduction in particle removal efficiency due to coagulation impairment or the neutralization of its oxidizing action due to the high alkalinity of the SMW. It is important to remember that $\mathrm{H}_{2} \mathrm{O}_{2}$ was used as a co oxidant with ozone and preferably, in basic medium, as a catalyst for the formation of hydroxyl radicals. However, the concentrations of ozone and peroxide used in the experiment had a small effect on the treatment.

Therefore, flotation has been shown to be the governing factor of the process and the main factor responsible for the efficiency of the treatment; its addition possibly impaired the quality of the coagulation, impacting the flotation performance, providing inferior results.

Table 4 shows the results of the analyses of the samples of milk wastewater industries.

Table 4. Average composition of milk wastewater samples.

\begin{tabular}{lccc}
\hline Parameters & Sample 1 & Sample 2 & Sample 3 \\
\hline Turbidity $\left(\mathrm{mg} \mathrm{L}^{-1}\right)$ & $3500.0( \pm 53.1)$ & $602.0( \pm 26.0)$ & $498.0( \pm 3.4)$ \\
TSS $\left(\mathrm{mg} \mathrm{L}^{-1}\right)$ & $2580.0( \pm 176.6)$ & $580.0( \pm 22.7)$ & $480.0( \pm 13.0)$ \\
pH & 7.52 & 12.55 & 6.03 \\
Delta color & $14.5( \pm 0.7)$ & $11.2( \pm 0.6)$ & $10.5( \pm 0.4)$ \\
COD $\left(\mathrm{mg} \mathrm{L}^{-1}\right)$ & $8876.4( \pm 187.7)$ & $3938.0( \pm 16.4)$ & $7653.8( \pm 27.0)$ \\
BOD $\left(\mathrm{mg} \mathrm{L}^{-1}\right)$ & $6810.0( \pm 64.3)$ & $2688.0( \pm 5.0)$ & $4590.0( \pm 17.2)$ \\
COD $/ \mathrm{BOD}^{-1}$ & 1.3 & 1.46 & 1.67 \\
O\&G $\left(\mathrm{mg} \mathrm{L}^{-1}\right)$ & $4296.7( \pm 62.6)$ & $101.0( \pm 1.6)$ & $1201.0( \pm 20.6)$ \\
TN $\left(\mathrm{mg} \mathrm{L}^{-1}\right)$ & $64.4( \pm 4.3)$ & $92.4( \pm 1.7)$ & $154.0( \pm 1.3)$ \\
TP $\left(\mathrm{mg} \mathrm{L}^{-1}\right)$ & $30.4( \pm 0.4)$ & $43.0( \pm 0.1)$ & $56.6( \pm 0.1)$ \\
\hline
\end{tabular}

From the data disclosed in Table 4, it can be observed that the characteristics of the wastewater of each industry varied widely, but the results are within the range of values found by Saraiva et al. (2009) and Begnini and Ribeiro (2014). Each industry has its follow-up of specific products, its production process and the general administration of the industry, which directly impacts the characteristic and quantity of effluent generated.

Sample 1 had white color (milk aspect), weak smell of fermented milk and suspended solids characteristic of cheese production. Sample 2 was greyish in color (sanitary sewer appearance), smelling cleaning products and no apparent suspended solids. Sample 3 presented a weak white to grayish color, smell of fermented milk with cleaning products and few suspended solids.

Among the three milk wastewater samples, Sample 1 presented the highest turbidity, TSS, COD, BOD, biodegradability and O\&G concentration. Comparing the samples with the synthetic wastewater (Table 1) used in previous stages, the COD and TSS values of the three milk effluent samples were higher. The other parameters were either higher or lower in each sample. In appearance, the sample that most resembled SMW was sample number 1.

Table 5 shows the results of the DAF and DOF tests using the wastewater samples of the three milk industries. 
Table 5. Results of the dissolved air flotation and dissolved ozone flotation.

\begin{tabular}{|c|c|c|c|c|c|c|c|c|c|}
\hline \multirow{2}{*}{ Sample } & \multirow{2}{*}{ Parameters } & \multicolumn{4}{|c|}{ DAF } & \multicolumn{4}{|c|}{ DOF } \\
\hline & & Mean & $\mathrm{SD}$ & $\mathrm{CV}$ & Efficiency & Mean & SD & $\mathrm{CV}$ & Efficiency \\
\hline \multirow{8}{*}{1} & Turbidity (mg L-1) & 117.6 & 4.3 & 3.7 & 96.6 (a) & 167.6 & 9.1 & 5.4 & $95.2(b)$ \\
\hline & Delta Color & 3.2 & 0.4 & 11.0 & 77.8 (a) & 4.0 & 0.3 & 6.7 & 72.7 (a) \\
\hline & $\mathrm{COD}\left(\mathrm{mg} \mathrm{L}^{-1}\right)$ & 2233.8 & 95.2 & 4.3 & 74.8 (a) & 2267.1 & 79.6 & 3.5 & 74.5 (a) \\
\hline & $\mathrm{BOD}\left(\mathrm{mg} \mathrm{L}^{-1}\right)$ & 960.0 & 18.3 & 1.9 & 85.9 (a) & 982.1 & 26.8 & 2.7 & 85.6 (a) \\
\hline & $\mathrm{O} \& \mathrm{G}\left(\mathrm{mg} \mathrm{L}^{-1}\right)$ & 218.0 & 12.0 & 5.5 & 94.9 (a) & 607.2 & 20.8 & 3.4 & 85.9 (b) \\
\hline & $\mathrm{TSS}\left(\mathrm{mg} \mathrm{L}^{-1}\right)$ & 190.4 & 26.6 & 13.9 & 92.6 (a) & 197.3 & 14.1 & 7.1 & 92.4 (a) \\
\hline & $\mathrm{TN}\left(\mathrm{mg} \mathrm{L}^{-1}\right)$ & 14.3 & 1.9 & 13.3 & 77.7 (a) & 14.6 & 1.9 & 13.3 & 77.4 (a) \\
\hline & $\mathrm{TP}\left(\mathrm{mg} \mathrm{L}^{-1}\right)$ & 18.5 & 0.5 & 2.7 & 39.2 (a) & 20.5 & 0.3 & 1.2 & $32.6(b)$ \\
\hline \multirow{8}{*}{2} & Turbidity $\left(\mathrm{mg} \mathrm{L}^{-1}\right)$ & 113.9 & 12.1 & 10.7 & 81.1 (a) & 166.8 & 5.5 & 3.3 & $72.3(b)$ \\
\hline & Delta Color & 5.9 & 0.7 & 11.8 & 47.4 (a) & 6.6 & 0.2 & 2.6 & 40.7 (a) \\
\hline & $\mathrm{COD}\left(\mathrm{mg} \mathrm{L}^{-1}\right)$ & 2576.8 & 21.8 & 0.8 & 34.6 (a) & 2657.8 & 21.8 & 0.8 & 32.5 (b) \\
\hline & BOD $\left(\mathrm{mg} \mathrm{L}^{-1}\right)$ & 1936.8 & 7.2 & 0.4 & 27.9 (a) & 1944.0 & 7.2 & 0.4 & 27.7 (a) \\
\hline & $\mathrm{O} \& \mathrm{G}\left(\mathrm{mg} \mathrm{L}^{-1}\right)$ & 0.0 & 0.0 & 0.0 & $100.0(a)$ & 0.0 & 0.0 & 0.0 & $100.0(a)$ \\
\hline & $\operatorname{TSS}\left(\mathrm{mg} \mathrm{L}^{-1}\right)$ & 80.8 & 7.3 & 9.1 & 86.1 (a) & 106.4 & 3.7 & 3.4 & 81.7 (b) \\
\hline & $\mathrm{TN}\left(\mathrm{mg} \mathrm{L}^{-1}\right)$ & 43.9 & 1.6 & 3.7 & 52.5 (a) & 42.9 & 1.6 & 3.8 & 53.5 (a) \\
\hline & $\mathrm{TP}\left(\mathrm{mg} \mathrm{L}^{-1}\right)$ & 42.5 & 0.2 & 0.4 & 1.2 (a) & 42.7 & 0.1 & 0.3 & 0.7 (b) \\
\hline \multirow{8}{*}{3} & Turbidity $\left(\mathrm{mg} \mathrm{L}^{-1}\right)$ & 305.6 & 4.2 & 1.4 & 38.6 (a) & 310.8 & 2.4 & 0.8 & 37.6 (a) \\
\hline & Delta Color & 11.2 & 1.0 & 9.0 & $-6.4(a)$ & 12.6 & 0.4 & 3.2 & -20.5 (a) \\
\hline & $\mathrm{COD}\left(\mathrm{mg} \mathrm{L}^{-1}\right)$ & 5015.4 & 34.3 & 0.7 & 34.5 (a) & 4721.9 & 40.2 & 0.9 & 38.3 (b) \\
\hline & $\mathrm{BOD}\left(\mathrm{mg} \mathrm{L}^{-1}\right)$ & 2612.0 & 18.3 & 0.7 & 43.1 (a) & 2280.0 & 52.3 & 2.3 & $50.3(b)$ \\
\hline & $\mathrm{O} \& \mathrm{G}\left(\mathrm{mg} \mathrm{L}^{-1}\right)$ & 232.0 & 8.5 & 3.7 & 80.7 (a) & 263.6 & 17.0 & 6.5 & 78.1 (a) \\
\hline & $\mathrm{TSS}\left(\mathrm{mg} \mathrm{L}^{-1}\right)$ & 273.8 & 14.9 & 5.5 & 43.0 (a) & 279.2 & 8.0 & 2.9 & 41.8 (a) \\
\hline & $\mathrm{TN}\left(\mathrm{mg} \mathrm{L}^{-1}\right)$ & 118.7 & 1.9 & 1.6 & 22.9 (a) & 119.8 & 1.9 & 1.6 & 22.2 (a) \\
\hline & $\mathrm{TP}\left(\mathrm{mg} \mathrm{L}^{-1}\right)$ & 42.5 & 0.2 & 0.4 & 24.9 (a) & 42.2 & 0.3 & 0.6 & 25.3 (a) \\
\hline
\end{tabular}

Note: Values on the same line followed by the same letter do not differ statistically by the Tukey test for a significance level equal to $5 \%$.

As can be seen in Table 5 (highlighted in bold), there was a significant difference in seven comparative analyses between DAF and DOF. There was a reduction in removal efficiency of turbidity, COD, O\&G, TSS and TP of samples 1 and 2 and an increase only in the removal efficiency of COD and BOD of Sample 3.

Among the samples evaluated, the best results of the analyzed parameters were obtained for Sample 1. This fact is possibly due to the greater presence of milk and cheese remains in this sample, which contain large quantities of casein, the main milk protein and which has an isoelectric point at $\mathrm{pH}$ equal to 4.6. At this $\mathrm{pH}$, or close to it, destabilization of the casein occurs and its natural coagulation takes place, leading to better removal efficiencies of these particles in flotation systems (Prazeres et al., 2012). During the research it was observed that the SMW used did not adequately represent the characteristics of the milk effluents in general and only with one of the three milk wastewater samples was it possible to obtain results similar to those obtained with the SMW. 
Lee and Song (2006) tested a continuous-flow pilot scale DOF system with an additional contact chamber to treat bovine wastewater. In that experiment, a recirculation ratio of $20 \%$, flotation time equal to $20 \mathrm{~min}$ and ozone concentrations of 40 to $200 \mathrm{mg} \mathrm{L}^{-1}$ in the feed air were used as operational parameters. According to the authors, it was possible to obtain removal efficiencies of COD, TSS, TN and TP of $88 \%, 92 \%, 67.7 \%$ and $94.6 \%$, respectively, with the system.

According to Lee and Song (2006), increase in ozone concentration has led to higher rates of COD removal and ozone in high concentrations improves the flotation process for two reasons: the first reason is that ozone improves coagulation by oxidizing the hydrophilic colloidal particles, making them hydrophobic and facilitating their removal; the second reason is due to the higher solubility of ozone in water, so higher concentrations of ozone causes an increase in the concentration of microbubbles, improving the efficiency of the process.

Lee et al. (2008) evaluated a DOF system and a common ozonation system (large bubbles), in laboratory-scale and pilot-scale, for the treatment of a secondary effluent from a sewage treatment plant. According to the authors, DOF has been shown to be a more effective ozonization technique compared to common ozonation. In the laboratory phase, the optimum ozone concentration found in the DOF was $6.1 \mathrm{mg} \mathrm{L}^{-1}$. The DOF pilot scale system evaluated for one month provided removal efficiencies of $86.9 \%$ of turbidity, $81 \%$ of total suspended solids, $72.6 \%$ of color, $82.4 \%$ of BOD and $92 \%$ of total phosphorus. However, lower removal efficiencies of $42.9 \%$ and $33.4 \%$ were obtained for COD and TN, respectively. Nearly $100 \%$ disinfection efficiency was achieved by the removal of heterotrophic bacteria and fecal coliforms.

An ozone system by microbubbles and macrobubbles for the treatment of a textile effluent was evaluated by Chu et al. (2008). In this work, the authors verified that with the use of the microbubbles, higher rates of mass transfer of ozone to the liquid medium were obtained, higher rates of color removal ( $80 \%$ in $140 \mathrm{~min}$ compared to $280 \mathrm{~min}$ ) and 20\% higher COD removal.

Beneventi et al. (2009) used a flotation system with ozone $\left(60 \mathrm{mg} \mathrm{L}^{-1}\right)$ using a flotation column and with recirculation of the clarified water to treat the effluent of a paper industry. According to the authors, it was possible to obtain an improvement in COD removal, compared to DAF, of 41 to $63 \%$, but there was no difference in effluent color removal efficiency (92\%).

The efficiency of DAF and DOF was compared by Wilinski and Naumczyk (2012), using a pilot scale system operated in continuous flow on treatment of wastewater from fruit processing. The authors observed a greater efficiency in treatment with DOF compared to DAF. In DOF, removal efficiencies of COD, soluble COD and BOD equal to $33.8 \%, 29.3 \%$ and $34.8 \%$, respectively, were obtained. In DAF, the removal efficiencies of COD, soluble COD and BOD were equal to $20.1 \%, 6.6 \%$ and $20.3 \%$, respectively.

Jin et al. (2015) used a pilot-scale DOF system, without pressurizing, to treat a secondary effluent from a sewage treatment plant. The operating conditions of the system were: recirculation ratio of $50 \%$, hydraulic retention time of 30 minutes and concentrations of ozone ranging from 0 to $1.6 \mathrm{mg} \mathrm{L}^{-1}$. The optimum ozone dosage determined by the authors was equal to $1.6 \mathrm{mg} \mathrm{L}^{-1}$. Removal efficiencies of $80 \%$ and $60 \%$, respectively, were obtained for color and TOC. Due to the ozone effect, there was also a large reduction in the molecular weight of the effluent components, from $6000 \mathrm{Da}$ to $3000 \mathrm{Da}$, with predominance of molecules up to $500 \mathrm{Da}$.

Contrary to the results of the mentioned authors, with the system used and under the conditions of this experiment, it was not possible to obtain an effective improvement in the removal efficiency of the evaluated parameters with the use of the ozone in the flotation process. In most of the tests there was a reduction in the removal efficiency of the evaluated parameters. The dissolved air flotation process had better performance and the physical mechanisms predominated in the treatment of the milk effluent.

The small or negligible effect of ozone in the process was possibly caused by the small

Rev. Ambient. Água vol. 15 n. 5, e2553 - Taubaté 2020 
concentration of ozone used $\left(19 \mathrm{mg} \mathrm{L}^{-1}\right)$ in the inlet air of the saturation chamber, which provided a small amount of dissolved ozone, around $21.6 \mathrm{mg}$, for the degradation of the organic effluent load (COD of 2233.8 to $5015.4 \mathrm{mg} \mathrm{L}^{-1}$ ).

Hydrogen peroxide was used in this experiment, with the function of co-oxidant and a catalyst for hydroxyl radical formation. Its punctual and pre-flotation addition had a similar effect to the ozone in the treatment, impairing the coagulation/flocculation and reducing particle removal efficiency during flotation. Usually, in the process called peroxone, the addition of $\mathrm{H}_{2} \mathrm{O}_{2}$ (via solution) and ozone (via gas flow) in the liquid medium is done together and continuously for long periods of time (10 to $360 \mathrm{~min}$ ), providing at the end of treatment an amount of oxidant much higher than the one used in this work (Catalkaya and Kargi, 2007; Li et al., 2013; Paschoalato et al., 2008).

Better results could be obtained with higher concentrations of ozone, since the concentration of ozone is small in relation to the high organic load of the milk effluent. Another important factor was the batch system used, which did not allow the recirculation of the clarified effluent and the reduced contact time $(\leq 2 \mathrm{~min})$ with ozone.

As can be seen in works of Lee and Song (2006), Lee et al. (2008), Chu et al. (2008), Kim et al. (2011), Wilinski and Naumczyk (2012) and Jin et al. (2015), in all those studies in which DOF had superior performance compared to DAF, it was possible to observe that at least one of these features existed: the ozonation had an application time $\geq 1 \mathrm{~h}$ using microbubbles; pilotscale systems operated at continuous flow and with recirculation of clarified effluent; an additional ozone tank was used that was incorporated into the system, called dissolved ozone flotation with pressurized ozone oxidation (DOF-PO2) (Kim et al., 2011; Lee and Song, 2006).

The recirculation and the additional tank increase the contact time of the dissolved ozone with the effluent to be treated, promoting the oxidation of pollutants and their degradation. Continuous flow systems would also enable the continuous addition of $\mathrm{H}_{2} \mathrm{O}_{2}$ at the ideal $\mathrm{H}_{2} \mathrm{O}_{2} / \mathrm{O}_{3}$ ratio for the formation of hydroxyl radicals, which would increase the degradation capacity of the pollutants and the overall efficiency of the system.

\section{CONCLUSIONS}

In the experimental conditions of the present work, dissolved ozone flotation did not demonstrate better performance compared to dissolved air flotation, with only a slight tendency to improve the removal of COD and BOD. In all tests of dissolved air flotation and dissolved ozone flotation, with and without the addition of hydrogen peroxide, better treatment results were obtained at $\mathrm{pH} 4$.

The tests with hydrogen peroxide at $\mathrm{H}_{2} \mathrm{O}_{2} / \mathrm{O}_{3}$ ratios of $0.5,1.0$ and 1.5 at $\mathrm{pH} 4$ demonstrated a gradual reduction in treatment efficiency, with a ratio increase and a slight tendency to increase at $\mathrm{pH} 11.4$, but still significatively below the results without hydrogen peroxide.

The results with synthetic effluent differed from the results with the three milk industry effluents, being closer in only one of them that contained more traces of milk and cheese residue.

It is suggested for future experiments, using the same flotation system, that tests be made using ozone concentrations equal to $100 \mathrm{mg} \mathrm{L}^{-1}$ or above. It is also suggested that tests be made using a flotation system operated at continuous flow, with recirculation of clarified effluent and an additional ozonation tank, and that tests with hydrogen peroxide be made with its continuous addition in the complementary ozonation tank, at $\mathrm{pH}$ ranges from 8 to 12 and with $\mathrm{H}_{2} \mathrm{O}_{2} / \mathrm{O}_{3}$ ratios varying from 0.5 to 3.0 .

\section{ACKNOWLEDGEMENTS}

This work was funded by National Council for Scientific and Technological Development 
(CNPq Grant 164598/2014-6) and Coordination for the Improvement of Higher Education Personnel (CAPES Finance Code 001).

\section{REFERENCES}

APHA; AWWA; WEF. Standard methods for the examination of water and wastewater. 22nd edition. Washington, 2012.

AHMADI, M.; GHANBARI, F. Degradation of organic pollutants by photoelectroperoxone/ZVI process: Synergistic, kinetic and feasibility studies. Journal of $\begin{array}{llllll}\text { Environmental } & \text { Management, } & \text { v. } & 228, & \text { p. }\end{array}$ https://doi.org/10.1016/j.jenvman.2018.08.102

ARSLAN, I. Treatability of a simulated dispersed dye-bath by ferrous iron coagulation, ozonation, and ferrous iron-catalyzed ozonation. Journal of Hazardous Materials, v. 85, n. 3, p. 229-241, 2001. http://doi.org/10.1016/S0304-3894(01)00232-1

BEGNINI, B. C.; RIBEIRO, H. B. Plano para redução de carga poluidora em indústria de lacticínios. Saúde e Meio Ambiente: Revista Interdisciplinar, v. 3, n. 1, p. 19-30, 2014. http://dx.doi.org/10.24302/sma.v3i1.519

BELTRÁN, F. J. Ozone reaction kinetics for water and wastewater systems. Boca Raton: Lewis Publishers, 2004.

BENEVENTI, D.; ALMEIDA, F.; MARLIN, N.; CURTIL, D.; SALGUEIRO, L.; AUROUSSEAU, M. Hydrodynamics and recovered papers deinking in an ozone flotation column. Chemical Engineering and Processing. v. 48, p. 1517-1526, 2009. http://doi:10.1016/j.cep.2009.10.007

CATALKAYA, E. C.; KARGI, F. Color, TOC and AOX removals from pulp mill effluent by advanced oxidation processes: A comparative study. Journal of Hazardous Materials, v. 139, n. 2, p. 244-253, 2007. http://doi.org/10.1016/j.jhazmat.2006.06.023

CHU, L.-B.; XING, X.-H.; YU, A.-F.; SUN, X.-L.; JURCIK, B. Enhanced treatment of practical textile wastewater by microbubble ozonation. Process Safety and Environmental Protection, v. 86, n. 5, p. 389-393, 2008. http://doi.org/10.1016/j.psep.2008.02.005

EDZWALD, J.; HAARHOFF, J. Dissolved air flotation for water clarification. New York: McGraw Hill Professional, 2011.

EDZWALD, J. K. Dissolved air flotation and me. Water Research, v. 44, n. 7, p. 2077-2106, 2010. http://doi.org/10.1016/j.watres.2009.12.040

JAAFARZADEH, N.; BARZEGAR, G.; GHANBARI, F. Photo assisted electro-peroxone to degrade 2,4-D herbicide: The effects of supporting electrolytes and determining mechanism. Process Safety and Environmental Protection, v. 111, p. 520-528, 2017. https://doi.org/10.1016/j.psep.2017.08.012

JIN, X.; JIN, P.; WANG, X. A study on the effects of ozone dosage on dissolved-ozone flotation (DOF) process performance. Water Science and Technology, v. 71, n. 9, p. 1423-1428, 2015. http://doi.dx.org/10.2166/wst.2015.115 
KIM, J. H.; KIM, H. S.; LEE, B. H. Combination of sequential batch reactor (SBR) and dissolved ozone flotation-pressurized ozone oxidation (DOF-PO2) processes for treatment of pigment processing wastewater. Environmental Engineering Research, v. 16, n. 2, p. 97-102, 2011. http://doi.dx.org/10.4491/eer.2011.16.2.97

LEE, B.; SONG, W. High concentration of ozone application by the DAF (Dissolved Air Flotation) system to treat livestock wastewater. WIT Transactions on Ecology and the Environment, v. 95, p. 561-569, 2006. http://doi.dx.org/10.2495/WP060551

LEE, B. H.; SONG, W. C.; MANNA, B.; HA, J. K. Dissolved ozone flotation (DOF)-a promising technology in municipal wastewater treatment. Desalination, v. 225, n. 1, p. 260-273, 2008. http://doi.org/10.1016/j.desal.2007.07.011

LI, Z.; YUAN, S.; QIU, C.; WANG, Y.; PAN, X.; WANG, J.; WANG, C.; ZUO, J. Effective degradation of refractory organic pollutants in landfill leachate by electro-peroxone treatment. Electrochimica Acta, n. 102 p. 174-182, 2013. http://doi.org/10.1016/j.electacta.2013.04.034

LIU, H.-L.; WANG, D.-S.; SHI, B.-Y.; WANG, M.; TANG, H.-X. Effects of pre-ozonation on organic matter removal by coagulation with IPF-PACl. Journal of Environmental Sciences (China), v. 18, n. 3, p. 453-458, 2006.

LIU, H.; GUO, X.; WANG, M.; JIAO, R.; SHI, J. Effects of interaction of ozonation and coagulation on coagulation results. Huan Jing Ke Xue= Huanjing Kexue, v. 36, n. 9, p. 3285-3291, 2015.

MACDOUGALL, D. B. Colour in food: Improving quality. Cambridge: Woodhead Publishing, 2002.

MARTINS, R. C.; QUINTA-FERREIRA, R. M. A review on the applications of ozonation for the treatment of real agro-industrial wastewaters. Ozone: Science \& Engineering, v. 36, n. 1, p. 3-35, 2014. http://dx.doi.org/10.1080/01919512.2013.842158

MAHMOUD, A.; FREIRE, R. S. Métodos emergentes para aumentar a eficiência do ozônio no tratamento de águas contaminadas. Química Nova, v. 30, n. 1, p. 198-205, 2007. http://dx.doi.org/10.1590/S0100-40422007000100032

NTAMPOU, X.; ZOUBOULIS, A.; SAMARAS, P. Appropriate combination of physicochemical methods (coagulation/flocculation and ozonation) for the efficient treatment of landfill leachates. Chemosphere, v. 62, n. 5, p. 722-730, 2006. http://doi.org/10.1016/j.chemosphere.2005.04.067

PASCHOALATO, C. F. P. R.; TRIMAILOVAS, M. R.; DI BERNARDO, L. Formação de subprodutos orgânicos halogenados nas operações de pré-oxidação com cloro, ozônio e peroxônio e pós-cloração em água conténdo substância húmica. Engenharia Sanitária e Ambiental, v. 13, n. 3, p. 313-322, 2008. https://doi.org/10.1590/S141341522008000300011

PRAZERES, A. R.; CARVALHO, F.; RIVAS, J. Cheese whey management: A review, Journal of Environmental Management, n. 110, p. 48-68, 2012. http://doi.dx.org/10.1016/j.jenvman.2012.05.018

RICHTER, C. A. Água: métodos e tecnologia de tratamento. São Paulo: Edgard Blucher, 2009. 
SARAIVA, C. B.; MENDONÇA, R. C. S.; SANTOS, A. L.; PEREIRA, D. A. Consumo de água e geração de efluentes em uma indústria de laticínios. Revista do Instituto de Laticínios Cândido Tostes, v. 64, n. 367, p. 10-18, 2009.

SHOKRI, A. Degradation of 2-Nitrophenol from Petrochemical Wastewater by Ozone. Russian Journal of Applied Chemistry, v. 88, n. 12, p. 2038-2043, 2015. https://doi.org/10.1134/S10704272150120216

SHOKRI, A.; MAHANPOOR, K.; SOODBAR, D. Degradation of Ortho-Toluidine in petrochemical wastewater by ozonation, $\mathrm{UV} / \mathrm{O} 3, \mathrm{O} 3 / \mathrm{H} 2 \mathrm{O} 2$ and $\mathrm{UV} / \mathrm{O} 3 / \mathrm{H} 2 \mathrm{O} 2$ processes. Desalination and Water Treatment, v. 57, n. 35, p. 16473-16482, 2015. https://doi.org/10.1080/19443994.2015.1085454

SILVA, L. V. C.; ANDRADE, M. V.; RODRIGUES, K.; MARINHO, G. Treatment of synthetic dairy wastewater in batch reactors inoculated with Aspergillus niger AN400. Engenharia Sanitária Ambiental, v. 18, p. 371-380, 2013. https://doi.org/10.1590/S1413-41522013000400009

WILINSKI, P.; NAUMCZYK, J. Dissolved Ozone Flotation as an innovative and prospect method for treatment of micropollutants and wastewater treatment costs reduction. In: WORLD WIDE WORKSHOP FOR YOUNG ENVIRONMENTAL SCIENTISTS, 12., 21-25 May 2012, Arcueil, France, 2012. Proceedings[...] Villeurbanne: CCSD, 2012. 